\title{
PROGRAM KEMITRAAN MASYARAKAT DI DHARMA WANITA FMIPA UNSRAT UNTUK KESEHATAN JANTUNG
}

\author{
Dingse Pandiangan*1, Paulina Y. Lamlean², Nelson Nainggolan ${ }^{3}$ \\ ${ }^{1}$ Jurusan Biologi FMIPA Universitas Sam Ratulangi Manado \\ 2. Program Studi Farmasi FMIPA Universitas Sam Ratulangi Manado \\ 3Jurusan Matematika FMIPA Universitas Sam Ratulangi Manado \\ *Penulis Korespondensi. Email: dingsepan@unsrat.ac.id
}

\begin{abstract}
ABSTRAK
Para perempuan tergabung dalam organisasi Dharma Wanita FMIPA (DWP) Unsrat perlu penerapan Program Kemitraan bagi Masyarakat (PKM) untuk mengatasi masalah kesehatan serta kebugaran secara fisik. Melalui penerapan PKM Senam Jantung Sehat dan Kebugaran tentu menambah kesehatan dan kebugaran fisik dan mental secara berkesinambungan. Metoda penerapan PKM dilakukan secara bertahap mulai dari pemberian panduan gerakan senam dan penerapan ke Sanggar Senam. Kemudian Senam Jantung Sehat dipelajari dan dilatih serta dipersiapkan jadi instruktur senam. Kemudian di Dharma Wanita FMIPA Unsrat dilakukan kegiatan: (1) perekrutan peserta atau ibu-ibu usia 35-55 tahun, (2) test darah dan kesehatan awal dan yang di uji baik di awal adalah berat badan, tinggi badan, tekanan darah. (3). Hasil penentuan tekanan darah yang bermasalah atau tinggi dilanjutkan dengan periksa darah kolesterol, asam urat, gula dengan alat Multicheck serta kebugarannya, (4) penerapan senam kebugaran 2 kali 1 minggu kemudian diuji kesehatan dan kebugaran akhir setelah penerapan PKM selesai. Parameter Senam jantung sehat dilakukan rutin setiap minggu atau 2 kali seminggu. Hasil pelaksanaan kegiatan PKM ini menunjukkan bahwa program PKM ini dapat meningkatkan semangat para anggota DWP FMIPA untuk memiliki pola hidup sehat dengan suka bersenam Jantung Sehat dan Senam Kebugaran lainnya. Kebiasaan suka bersenam Jantung Sehat dan menjadi gaya hidup menimbulkan rumah tangganya bahagia dan sehat serta lebih bijaksana. Ditemukan juga hasil dari kegiatan ini menjadi cikal bakal tradisi di DWP FMIPA untuk berolah raga senam 1 kali setiap minggunya (minimal) secara pribadi dan terorganisir 2 kali satu bulan oleh pimpinan DWP FMIPA. Hasil uji kebugaran juga menunjukkan adanya kemajuan kebugaran dari sebelum diterapkannya PKM senam jantung sehat dan kebugaran. Sanggar Senam yang menjadi Mitra mendapatkan panduan dan jenis senam baru untuk dilatihkan di Sanggar Senam Mitra kegiatan.
\end{abstract}

Kata Kunci: Dharma Wanita; FIMPA Unsrat; Kebugaran; Kesehatan Jantung;

\section{PENDAHULUAN}

\section{Analisis Situasi}

Olahraga adalah salah satu bentuk dari upaya peningkatan kualitas Kebugaran Ibu-Ibu yang tinggal di rumah melalui fisiknya yang diarahkan pada pembentukan watak dan kepribadian, disiplin dan sportivitas yang tinggi, serta peningkatan prestasi yang dapat membangkitkan rasa kebanggaan nasional (GBHN Tap MPR No. II/MPR/1988). Olahraga juga merupakan serangkaian gerak raga yang teratur dan terencana untuk memelihara gerak dan meningkatkan kemampuan gerak (Giriwijoyo dan Muchtamaji, 2005).
Dharma Wanita FMIPA Unsrat berada di Universitas Sam Ratulangi yang memiliki keanggotaannya terdiri dari seluruh tenaga Akademik Perempuan, Tenaga Kependidikan dan Istri Aparatur Sipil Negara dan honorer yang perempuan termasuk dalam komunitas Dharma Wanita FMIPA UNSRAT Manado. Keanggotaannya berada pada usia yang bervariasi mulai usia 20 sampai 60 tahun. Selama ini program atau kegiatan dari Dharma Wanita adalah salah satunya Zumba pada hari Jumat pagi setiap awal bulan dan minggu ketiga, namun sering terkendala kehadiran para anggota karena Zumba termasuk olah raga yang sangat aktif dan 
Jurnal Perempuan dan Anak Indonesia

cocok untuk usia anak-anak sampai 45 tahunan. Sedangkan Usia di atas 40 tahun sering mengeluh ingin senam yang sesuai usia mereka seperti Senam Jantung Sehat atau Yoga. Kendala yang di hadapi tidak ada instruktur untuk Jantung Sehat tersebut. Oleh sebab itu melalui kegiatan PKM ini akan dilakukan pembinaan atau pelatihan pada pelatih di Global Fitness untuk siap jadi instruktur dan dan akan menjadi instruktur di Dharma Wanita pada umumnya se Unsrat yang pada akhirnya para Dharma Wanita yang punya bakat akan bisa menjadi instruktru di tempat masingmasing.

Permasalah lainnya yang terjadi selama ini adalah Dhrarma Wanita tidak ada dana selain dari Iuran anggota saja. Selama ini Iuran per bulan Rp. 10.000 di FMIPA UNSRAT ada yang potong gaji dan ada yang setor sendiri. Dari total anggota yang aktif hanya terkumpul sekitar Rp. 600.000. Sedangkan Instruktur Zumba sekali Senam bayar Rp. 300.000 dan dua kali sebulan maka Iuran habis semua untuk Zumba. Hal ini yang mendorong kami Tim untuk melakukan kegiatan PKM ini bagi DWP FMIPA Unsrat yang sangt antusias dalam berolahraga dan mengikuti kebersamaan dengan menggunakan Dana yang ada untuk melatih para Instruktur di Global Fitness terlebih dahulu dan membayar mereka lebih murah misalnya Rp. 200.000 per pertemuan atau lebih rendah lagi untuk Senam Jantung Sehat supaya ada perimbangan untuk semua usia anggota yang ada. Oleh sebab itu kegiatan PKM ini sangat urgen untuk dilakukan.

\section{Tujuan dan Manfaat Kegiatan}

Memberikan motivasi dan inovasi yang baru kepada masyarakat terutama kepada Ibu-Ibu rumah tangga untuk mampu mengelola waktu dan kegugaran fisiknya yang dapat mendukung kesejahteraan rumah tangga dan sekaligus kesejahtraan dan keamanan lingkungan. Ditargetkan melalui kegiatan PKM ini akan meningkatkan semangat ibu-ibu DWP MIPA untuk memiliki pola hidup sehat dengan suka bersenam kebugaran dan menjadi gaya hidup sehingga rumah tangganya bahagia yang diawali dengan ibu rumah tangga yang bijaksana. Target lainnya diharapkan menjadikan cikal bakal tradisi di masyarakat Dharma Wanita untuk berolah raga senam 1 kali setiap minggunya (minimal). Luarannya hasil uji Kebugaran yang menunjukkan adanya kemajuan Kebugaran dari sebelum diterapkannya PKM senam Jantung Sehat dan kebugaran ini ditambah pemanfaatan minuman fungsional pasote akan meningkatkan kebugaran DWP FMIPA UNSRAT. Senam Global Fitness akan memperoleh panduan dan Senam kebugaran baru untuk dikembangkan bagi peserta didiknya setelah kegiatan selesai.

\section{METODE PELAKSANAAN}

Untuk mengatasi permasalahan yang dihadapi Dharma Wanita FMIPA Unsrat supaya semua usia dapat menikmati kebersamaan berolah raga setiap Jumat pagi dan lebih bugar maka dilakukan atau dilaksanakan kegiatan pengabdian kepada masyarakat melalui Program PKM ini yang akan dilaksanakan secara bertahap antara lain:

\section{Pemilihan Anggota Peserta Senam DWP FMIPA UNSRAT}

Anggota (peserta senam) yang digunakan untuk pelaksanaan PKM ini ini adalah seluruh anggota Dharma Wanita FMIPA Unsrat yang berusia 25-60 tahun.

\section{Test Kebugaran Awal}

Sebelum penerapan Program Jantung Sehat diterapkan pertama sekali dilakukan 
penimbangan berat badan, tinggi badan sehingga diperoleh indeks berat badan.

Disamping itu diukur tekanan darah. Dari hasil penimbangan BB dan Tekanan darah ada indikasi kesehatan terganggu maka dilanjutkan pengukuran kandungan kolesterol darah, asam urat dan gula darahnya dengan alat Autocheck. Hal ini perlu untuk menentukan kondisi Kebugaran ibu-ibu Dharma Wanita FMIPA Unsrat sebelum dilakukan PKM tersebut dengan Kash Step Test.

\section{Pelaksanaan Senam Jantung Sehat dan Kebugaran serta Zumba}

Senam Jantung Sehat dan kebugaran lainya ini dilaksanakan setiap minggu hari Jumat pagi jam 6.30 pagi di lapangan FMIPA Unsrat dengan Instruktur dari Senam Global Fitness dan BKOM (Balai Kesehatan Olahraga Masyarakat). Intruktur pertama dari BKOM untuk Senam Kebugaran atau Jantung Sehat Seri ketiga dan Instruktur kedua dari Global Fitness untuk Senam Aerobic dan dan Zumba. Pelaksanaannya 3 tahapan yaitu Tahap I adalah pemanasan dan inti Senam Kebugaran 30 menit, lanjut tahap II Senam Aerobik pemanasn dan inti selama 30 menit, kemudian Tahap III senam Zumba inti 30 menit yang akhirnya ditutup dengan pendinginan. Setiap minggu kegiatan senam ini dilakukan dengn susunan acara berdoa dulu yang dipinpin oleh pelaksana, kemudian senam (Jantung Seghat, Kebugaran, Aerobik dan Zumba), Pengarahan dan pemeriksaan kesehatan, doa tutup oleh salah seorang pelaksanan atau Ketua atau Seamas di MIPA. Acara tersebut ini dilakukan setiap minggu tahapan-tahapannya seperti Gambar 1.

Senam Bugar Indonesia adalah senam yang disusun dan diluncurkan pada tahun 2006 oleh Persatuan Wanita Olahraga Seluruh Indonesia (Perwosi) yang merupakan induk organisasi cabang olahraga pada wanita di bawah naungan Komite Olahraga Nasional Indonesia yang didukung oleh Kementerian Pemuda dan Olahraga. Senam ini diciptakan untuk

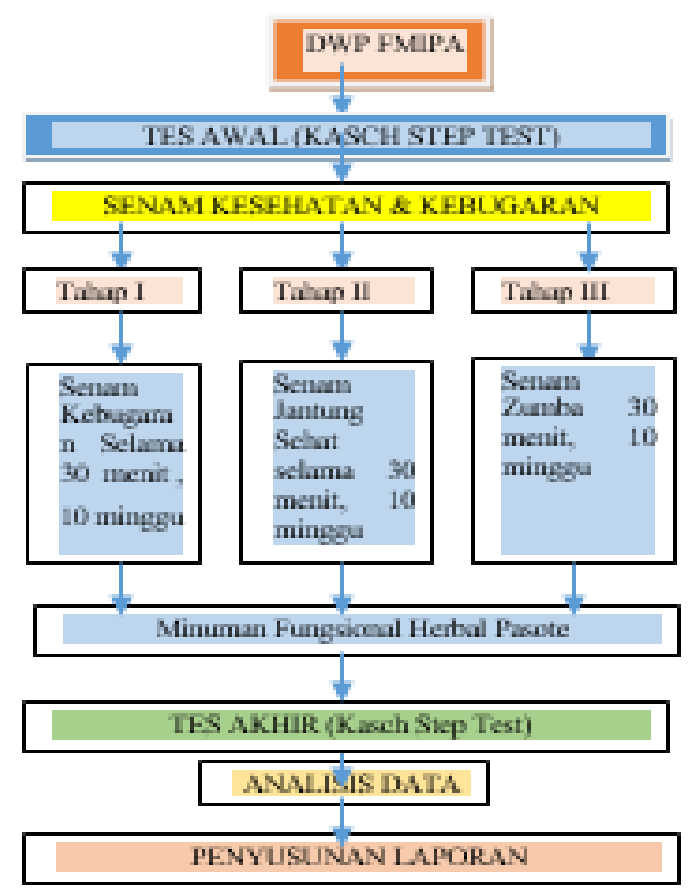

penciptakan keselarasan dan keseimbangan gerak dalam membantu otot-otot tubuh meningkatkan

Gambar 1. Bagan pelaksanaan kegiatan PKM Senam Jantung Sehat dan Kebugaran di Dharma Wanita FMIPA Unsrat atau Senam Zumba

kesehatan dan kebugaran (Anonim, 2006). Senam tersebut memiliki gerakan yang dinamis, mudah dilakukan, melibatkan otot-otot gerak pada kedua ekstremitas dan musiknya menimbulkan rasa gembira dan bersemangat, selain itu kedua senam tersebut mengandung unsur budaya yang kental dalam gerakan dan musiknya. Struktur Senam ini terdiri dari Pemanasan, Latihan Inti dan Pendinginan.

\section{Monitoring dan Evaluasi Kegiatan}

Hasil penerapan terus di pantau sampai dua bulan berjalan dan dilakukan tanya jawab mengenai kebugaran yang dirasakan para ibu-ibu disamping itu dilakukan pengukuran berat badan dan tinggi badan serta tekanan darah serta kandungan kolesterol atau gula darah. Hasil pengukuran dilakukan perbandingan dengan hasil pemeriksaan Kebugaran sebelumnya antara lain, 
JPAI

Jurnal Perempuan dan Anak Indonesia

berat badan, tinggi badan, kebugaran, kolesterol, gula dan tekanan darah. Hasil yang diharapkan meningkatkan Kebugaran para ibu-ibu Dharma Wanita FMIPA Unsrat.

Kegiatan ini menggunakan instrument untuk mendapatkan tingkat kebugaran. Untuk menentukan tingkat kebugaran jasmani diperoleh dari data primer yang dikumpulkan dengan metode Harvard Step Test (HST), yaitu meminta responden untuk naik turun bangku secara terus menerus dan mengikuti irama yang teratur sebanyak 120 kali per menit selama 5 menit. Setelah itu nadi dihitung sebanyak 3 kali, dengan lama perhitungan masing-masing 30 detik. Nadi dihitung pada 1 menit sampai 1 menit 30 detik, 2 menit sampai 2 menit 30 detik, dan 3 menit sampai 3 menit 30 detik. Kemudian hasil perhitungan denyut nadi dimasukkan ke dalam rumus kebugaran jasmani. Kebugaran Jasmani $=$ Waktu yang dibutuhkan (detik) $\times 1002 \times($ denyut nadi $1+$ nadi 2 + nadi 3 ) .

Hasil perhitungan kemudian disesuaikan dengan standar kategori kebugaran jasmani dengan cara lambat (Mackenzie, 2013) seperti pada Tabel 1. Sebagai pembanding digunakan juga alat Treatmeal dengan menghitung denyut nadi jantung. Dapat seperti pada tabel 1dilihat seperti pada Gambar 2. Sehingga dampak kesehtan jantung terlihat jelas pada setiap peserta.

Tabel 1. Standar Kategori HST (Mackenzie, 2013).

\begin{tabular}{|l|l|l|}
\hline \multirow{2}{*}{ Kebugaran Jasmani } & \multicolumn{2}{|c|}{ Hasil Perhitungan } \\
\cline { 2 - 3 } & Laki-Laki & Perempuan \\
\hline Sangat Baik & $>90,0$ & $>86,0$ \\
\hline Baik & $80,0-90,0$ & $76,0-86,0$ \\
\hline Cukup & $65,0-79,9$ & $61,0-75,9$ \\
\hline Kurang & $55,0-64,9$ & $50,0-60,9$ \\
\hline Sangat Kurang & $<55$ & $<50$ \\
\hline
\end{tabular}

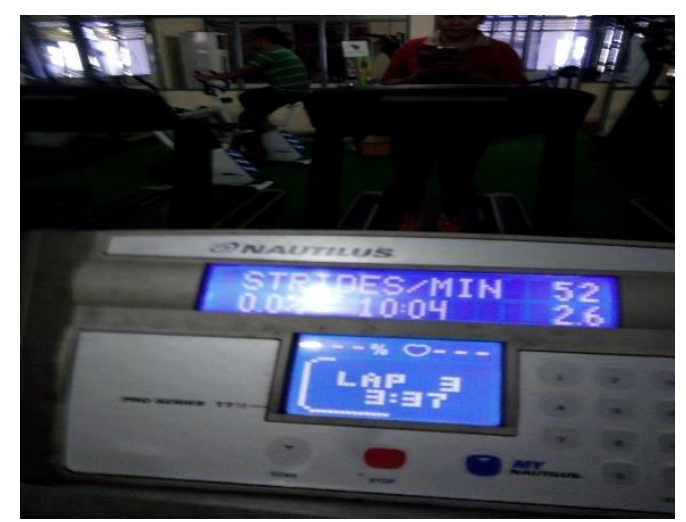

Gambar 2. Pengukuran kebugaran dengan treatmeal yang digital menunjukkan kebugaran seseorang, yang dibarengi dengan pengukuran VO2Max

\section{HASIL DAN PEMBAHASAN}

\section{Persiapan dan koordinasi kegiatan}

Koordinasi pelaksanaan kegiatan dilakukan dengan sesama pelaksana kegiatan pada awalnya. Kemudian diberi pembagian tugas. Kemudian koordinasi dengan Dinas terkait (Dinas Kesehatan) dan BKOM Sulawesi Utara, demikian dengan Mitra Senam Global Fitnes yang akan menjadi instruktur senam yang dimaksud. Pelaksanaan kegiatan dikoordinasikan bersamasama disertai dengan pelaksanaan kegiatan yang sangat bersinergis (Gambar 3)

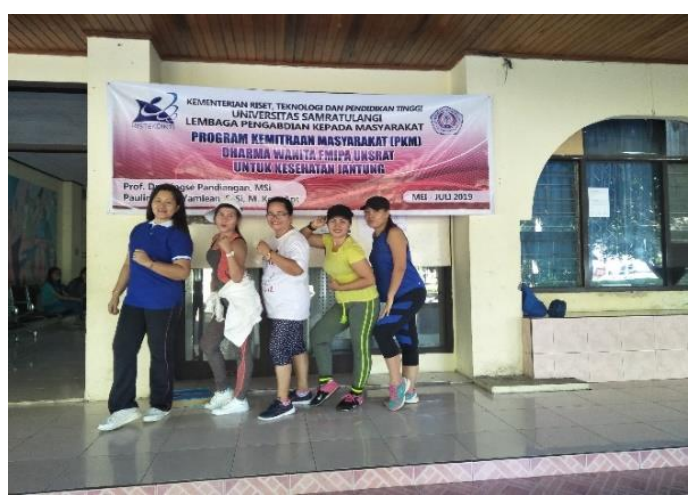

Gambar 3. Pelaksana dengan para instruktur dan peserta DWP UNSRAT

\section{Sosialisasi dan pengarahan serta perekrutan peserta senam jantung sehat}


Berdasarkan pada pertemuan awal yang dilakukan pada tanggal 8 Juli 2019 Dharma Wanita yang hadir pada saat sosialisasi dihadiri oleh sekitar 50 orang. Sebagian peserta diakhir kegiatan melakukan foto bersama (Gambar 3). Meskipun sebenarnya peserta Dharma Wanita secara administrasi adalah sekitar 100 orang, namun sedikit yang mau memberikan diri untuk aktif mengikuti setiap pertemuan setiap bulan minggu pertama (tanggal 8 setiap bulannya).

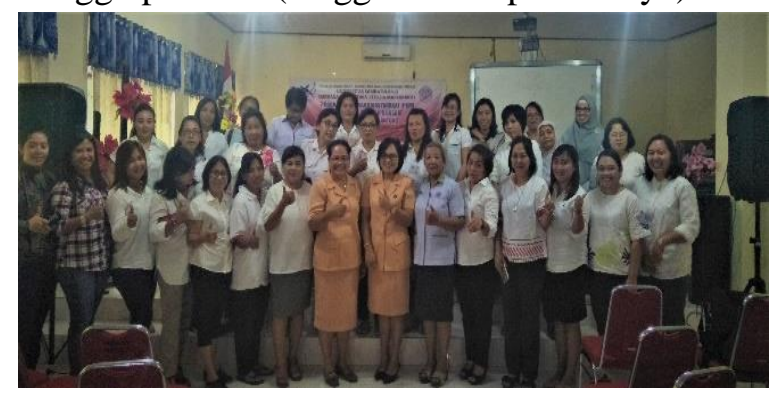

Gambar 3. Foto bersama sebagian peserta di akhir sesi para peserta penyuluhan dan sosialisasi tentang pentingnya kesehatan Jantung dan langkah langkah sehat yang harus dijalankan.

Materi sosialisasi di jelaskan tentang kesehatan jantung itu yang sangat penting dan gejala-gejala serangan jantung serta tumbuhan yang banyak mengandung antioksidan atau antidegeneratif disampaikan kepada peserta oleh Pelaksanan didampingi Pimpinan Dharma Wanita FMIPA UNSRAT (Gambar 4). Peserta masih bervariasi mulai dari pimpinan dan anggota DWP, Dosen, Pegawai atau tenaga kependidikan, honorer mulai dari usia 24 tahun sampai usia 60 tahun. (Gambar 5)

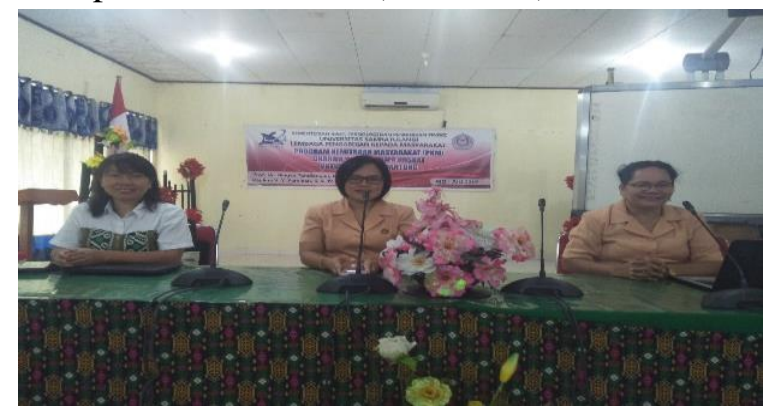

Gambar 4. Sosialisasi Kesehatan Jantung dan Olah Raga oleh Pelaksana didampingi

\section{Pimpinan Dharma Wanita FMIPA UNSRAT}

\section{Pelatihan Instruktur yang Berasal dari DWP FMIPA UNSRAT}

Setelah program PKM ini permasalahan yang pernah dihadapi sebelumnya mengenai tidak adanya instruktur untuk Jantung Sehat sudah teratasi sebab sudah ada instruktur dari DWP MIPA. Pelatihan instruktur yang punya bakat instruktur senam di Sanggar Senam terlebih dahulu di awal program ini oleh Instruktur dan kawan kawannya (Gambar 5). Oleh sebab itu melalui kegiatan PKM ini telah dilakukan pembinaan atau pelatihan pada pelatih di Senam Global Fitness selama satu bulan untuk siap jadi instruktur dan akan menjadi instruktur di Dharma Wanita pada umumnya se Unsrat yang pada akhirnya para Dharma Wanita yang punya bakat akan bisa menjadi instruktur di tempat masingmasing.

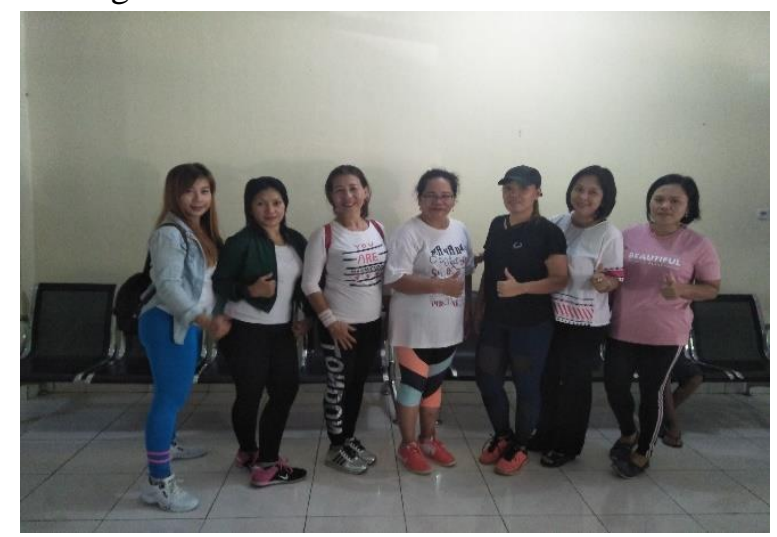

Gambar 5. Foto bersama instruktur senam Jantung Sehat (tiga orang paling kiri) dan Pimpinan Dharma Wanita (paling kanan) serta Pelaksana (tengah)

Solusi untuk mengatasi mahalnya biaya untuk intruktur maka dilakukan pelatihan kepada para ibu-ibu yang berbakat jadi instruktur sehingga mereka bisa menekan harga untuk instruktur. Misalnya Instruktur Zumba sekali Senam bayar Rp. 300.000 dan dua kali sebulan maka Iuran habis semua untuk Zumba. untuk melatih para Instruktur Sanggar Mitra terlebih dahulu dan membayar mereka lebih murah misalnya Rp. 200.000 per pertemuan atau lebih 
Jurnal Perempuan dan Anak Indonesia

rendah lagi untuk Senam Jantung Sehat supaya ada perimbangan untuk semua usia anggota yang ada.

\section{Pelaksanaan Senam Jantung Sehat dan Senam Kebugaran lainnya}

Kegiatan PKM untuk jantung sehat dari Dharma Wanita FMIPA dilakukan pada setiap hari Jumat pagi setiap minggu. Senam Jantung Sehat pada awalnya banyak diikuti peserta dan sangat bervariasi usianya (Tabel 2). Tabel 2 merupakan data yang mempunyai tekanan darah diatas $125 \mathrm{mmHg}$ dan dilanjutkan dengan pengukuran Kolesterol, Gula dan Asam Urat darahnya dengan Autocheck strip. Jenis kelamin peserta juga ada beberapa laki-laki yang tergabung dan menjadi peserta ada 6 orang yang bermasalah tekanan darahnya, sedangkan laki laki lainnya tidak diukur kadar gula, kolesterol, asam urat darahnya.

Proporsi laki laki dan perempuan adalah 4 berbanding 17 orang. Usia yang paling dominan menjadi peserta adalah usia 40-49 tahun dengan jumlah 10 orang dari 23 orang adalah $43 \%$. Sedangkan usia diatas 50 tahun sebanyak $8 \%$ dan diatas usia 60 tahun adalah $26 \%$ (Tabel 2).

Senam Jantung sehat kurang diminati usia muda mereka merasa kurang gerakan atau terlalu teratur. Kemudian di pertemuan atau senam berikutnya dikombinasikan dengan senam Aerobik, Zumba dan Yoga secara berkesinambungan. Senam Zumba digunakan untuk yang berusia lebih muda sekitar 20- 40 tahun karena karena banyak gerakan yang melompat dan berputar. Zumba juga termasuk olah raga yang sangat aktif dan cocok untuk usia anak-anak sampai 40 tahun (Gambar 5)

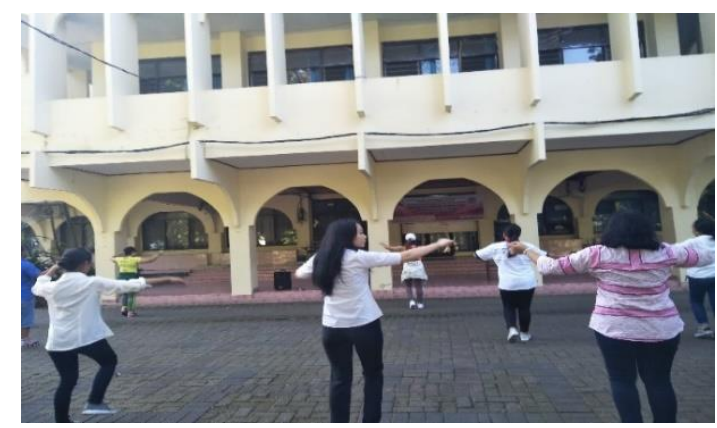

Gambar 5. Peserta Senam Jantung Sehat dan Senam Kebugaran lainnya usia tua (dibawah usia 40 tahun)

Sebelum kegiatan PKM ini DWP yang usia di atas 40 tahun sering mengeluh ingin senam yang sesuai usia mereka seperti Senam Jantung Sehat atau Yoga. Setelah kegiatan ini jumlah peserta yang mau bergabung untuk senam bertambah termasuk yang sudah usia diatas 50 tahun lebih seperti Prof. Dr. Herny Simbala bergabung di Senam Jantung Sehat (Gambar 6), yang berbaju merah dalam Gambar tersebut.
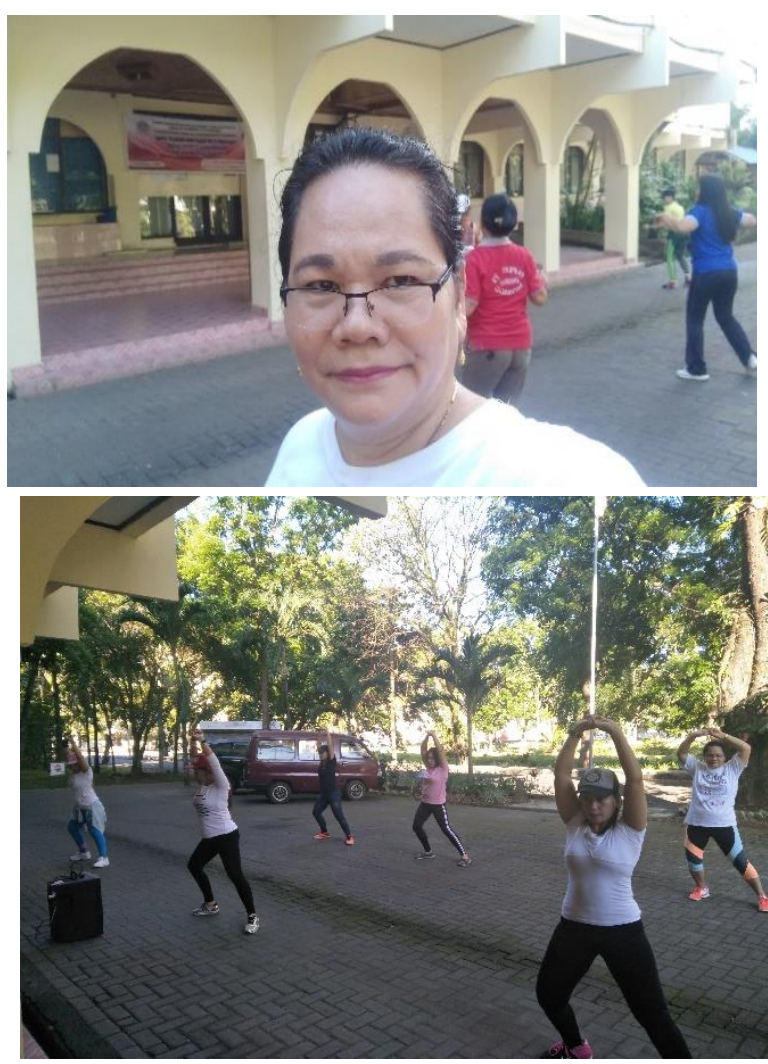

Gambar 6. Peserta Senam Jantung Sehat yang pesertanya berusia 45 ke atas kebanyakan yang hadir. Seorang Profesor yang berbaju merah dan baju putih. 
Tabel 2. Hasil pemeriksaan darah (Gula, Asam Urat, kolesterol) sesaat (tanpa puasa) dalam mg/dL dari peserta senam Jantung Sehat diawal kegiatan PKM di Dharma Wanita FMIPA UNSRAT yang sebelumnya diuji tekanan darahnya lebih tinggi dari normalnya $(120 / 80 \mathrm{~mm} \mathrm{Hg})$

\begin{tabular}{|l|c|c|c|c|c|c|}
\hline Nama Peserta & $\begin{array}{c}\text { Umur } \\
\text { (Tahun) }\end{array}$ & $\begin{array}{c}\text { Jenis } \\
\text { Kelamin }\end{array}$ & $\begin{array}{c}\text { Gula } \\
\text { darah }\end{array}$ & $\begin{array}{c}\text { Asam } \\
\text { Urat }\end{array}$ & Kolesterol & $\begin{array}{c}\text { Tekanan } \\
\text { Darah }\end{array}$ \\
\hline Peserta 1 & 48 & $\mathrm{P}$ & 139 & 7,1 & 200 & $135 / 89$ \\
\hline Peserta 2 & 46 & $\mathrm{P}$ & 116 & 6,3 & 309 & $156 / 96$ \\
\hline Peserta 3 & 31 & $\mathrm{P}$ & 158 & 6,3 & 207 & $130 / 85$ \\
\hline Peserta 4 & 68 & $\mathrm{P}$ & 335 & 6,3 & 319 & $156 / 96$ \\
\hline Peserta 5 & 30 & $\mathrm{P}$ & 129 & 5,4 & 269 & $135 / 85$ \\
\hline Peserta 6 & 36 & $\mathrm{P}$ & 121 & 6,9 & 302 & $145 / 85$ \\
\hline Peserta 7 & 61 & $\mathrm{P}$ & 122 & 6,3 & 279 & $140 / 91$ \\
\hline Peserta 8 & 41 & $\mathrm{P}$ & 112 & 5,8 & 251 & $140 / 86$ \\
\hline Peserta 9 & 47 & $\mathrm{P}$ & 168 & 7,3 & 290 & $135 / 89$ \\
\hline Peserta 10 & 44 & $\mathrm{P}$ & 334 & 5,4 & 214 & $145 / 90$ \\
\hline Peserta 11 & 61 & $\mathrm{P}$ & 140 & 7,4 & 204 & $145 / 92$ \\
\hline Peserta 12 & 59 & $\mathrm{~L}$ & 152 & 6,0 & 264 & $130 / 86$ \\
\hline Peserta 13 & 66 & $\mathrm{P}$ & 147 & 8,8 & 372 & $142 / 90$ \\
\hline Peserta 14 & 46 & $\mathrm{~L}$ & 129 & 5,7 & 209 & $128 / 86$ \\
\hline Peserta 15 & 18 & $\mathrm{P}$ & 112 & 5,7 & 222 & $129 / 81$ \\
\hline Peserta 16 & 23 & $\mathrm{~L}$ & 124 & 5,7 & 251 & $131 / 83$ \\
\hline Peserta 17 & 63 & $\mathrm{P}$ & 142 & 7,0 & 371 & $150 / 92$ \\
\hline Peserta 18 & 63 & $\mathrm{P}$ & 128 & 9,2 & 267 & $146 / 89$ \\
\hline Peserta 19 & 45 & $\mathrm{~L}$ & 130 & 7,6 & 141 & $130 / 90$ \\
\hline Peserta 20 & 49 & $\mathrm{~L}$ & 124 & 6,3 & 224 & $132 / 92$ \\
\hline Peserta 21 & 42 & $\mathrm{~L}$ & 187 & 6,0 & 264 & $137 / 95$ \\
\hline Peserta 22 & 59 & $\mathrm{P}$ & 237 & 7,5 & 147 & $135 / 92$ \\
\hline Peserta 23 & 41 & $\mathrm{P}$ & 119 & 5,2 & 277 & $134 / 85$ \\
\hline Rata-rata & $\mathbf{4 7 . 2 6}$ & & $\mathbf{1 5 6 . 7 4}$ & $\mathbf{6 . 5 7 4}$ & $\mathbf{2 5 8 . 8 3}$ & \\
\hline
\end{tabular}

Usia: $<30$ tahun $=2$ orang

30-39 tahun $=3$ orang

$40-49$ tahun $=10$ orang

$50-59$ tahun $=2$ orang

$>60$ tahun $=6$ orang
Jenis Kelamin $\quad \mathrm{L}=$ laki-laki sebanyak 6 orang

$\mathrm{P}=$ perempuan sebanyak 17 orang

\section{Kegiatan senam kebugaran rutin setiap hari Jumat mulai jam 6.30 WITA.}

Kegiatan dilakukan sama seperti yang dilakukan seperti pada kegiatan sosialisasi di atas. Perbedaannya pemateri atau pembicara tidak dilakukan lagi namun hanya arahan dan dorongan serta ajakan agar hidup sehat dan bugar dengan melakukan orahraga yang rutin dan teratur. Kegiatan rutin setiap minggu seperti pada Gambar 5 dan juga jadwal acara seperti yang dilampirkan. Dilakukan uji kesehatan atau kebugaran pada awal kegiatan pada minggu berikutnya (Tabel 2). Kemudian dilakukan juga pengukuran tekanan darah setiap minggu sebelum dan sesudah olah raga bagi yang merasa kesehatannya kurang fit.

\section{KESIMPULAN DAN SARAN}

\section{Kesimpulan}

Kesimpulan pelaksanaan kegiatan PKM menunjukkan Program PKM ini dapat 
meningkatkan semangat para anggota DWP FMIPA untuk memiliki pola hidup sehat dengan suka bersenam Jantung Sehat dan Senam Kebugaran lainnya. Kebiasaan suka bersenam Jantung Sehat dan menjadi gaya hidup menghasilkan tubuh yang sehat yang berdampak pada rumah tangga bahagia dan sehat serta lebih bijaksana. Ditemukan juga luaran dari kegiatan ini menjadi cikal bakal tradisi di DWP FMIPA untuk berolah raga senam 1 kali setiap minggunya (minimal) secara pribadi dan terorganisir 2 kali satu bulan oleh pimpinan DWP FMIPA. Luarannya hasil uji kebugaran yang menunjukkan adanya kemajuan kebugaran dari sebelum diterapkannya PKM senam jantung sehat dan kebugaran. Sanggar Senam yang menjadi Mitra mendapatkan panduan dan jenis senam baru untuk dilatihkan di Sanggar Senam.

Output yang lebih menonjol adalah adanya UKM Senam yang baru terbentuk setelah kegiatan ini berakhir. Ditemukan juga bahwa senam yang lebih diminati DWP FMIPA adalah orahraga kebugaran Senam Zumba bagi usia muda dan Jantung Sehat serta Yoga bagi usia diatas 50 tahun.

\section{Saran}

Potensi dari PKM Jantung Sehat ini sebaiknya dikembangkan menjadi suatu UKM baru untuk usia yang diatas 45 tahun ke atas karena lebih diminati oleh orang tua. Pemuda atau usia muda (dibawah 45 tahun) lebih menyukai Zumba dan Aerobik, yang sudah mulai dikembangkan di MIPA UNSRAT. Disarankan juga sebaiknya pimpinan UKM Senam MIPA UNSRAT di sebaiknya dari Dharma Wanita FMIPA Unsrat karena mereka leluasa waktu mereka untuk mengkoordinir kegiatan.

\section{UCAPAN TERIMAKASIH}

Terimakasih diucapkan kepada:
1. Ketua Dharma Wanita FMIPA UNSRAT dan jajarannya.

2. Rektor dan Ketua LPPM UNSRAT yang telah memberikan bantuan dana pada pelaksanaan kegiatan ini melalui Proram PKM PNBP.

\section{DAFTAR PUSTAKA}

Adiatmika, I.P.G. 2002. Pengukuran Kesegaran Jasmani. Denpasar: Udayana University Press.

Anonim. 1994. Pedoman Pengukuran Kesegaran Jasmani. Jakarta : Depkes RI, Dirjen Pembinaan Kebugaran Masyarakat, Dir. Bina Marga Upaya Kes. Puskesmas.

Anonim. 2001. Profil Kebugaran Indonesia 2001. Jakarta : Depkes RI

Anonim. 2002. Senam Ayo Bersatu. Federasi Olahraga Rekreasi Masyarakat Indonesia (FORMI). Jakarta : FORMI.

Anonim. 2006. Senam Bugar Indonesia. Jakarta : KONI, Persatuan Wanita Olahraga Seluruh Indonesia (PERWOSI).

Anonim. 2007. Laporan Sport Development Index tahun 2006. Jakarta : Kementrian Negara Pemuda Dan Olahraga.

Anonim. 2009. Pengembangan Persyaratan Fisik Dalam Senam. [Cited 2013 Feb 24]. Available at: http://file.upi.edu/Direktori/FPOK/JUR_PE ND_OLAHRAGA.

Anonim. 2012. Tinjauan Pustaka Nutrisi Atlit dan Komponen Biomotori k. [Cited 2013 Mar 2]. Available at : repository.ipb.ac.id/bitstream/handle/ 123456789/53489/bab\%20II\%tunjauan\%p ustaka.pdf

Anonim. 2012a. Senam Ayo Bergerak. Federasi Olahraga Rekreasi Masyarakat Indonesia (FORMI) Indonesia. Jakarta : FORMI Anonim. 2012b. Kebugaran. [Cited 2013 Feb 23]. Available at : http://id.wikipedia.org/wiki/Kebugaran

Anonim. 2013. Physical Activity Fact Sheets. World Health Organization. [Cited 2013 Feb 24]. Available at : www.who.int/physical_activity/en

Balley, A. 1994. Pedoman Atlet, Teknik Peningkatan Ketangkasan dan Stamina. 
Prosedur Pengembangan Ketahanan Tubuh.

Jakarta : Dahara Price.

Bell, D.G, Jacobs I. 1992. Blood La ctate Response to the Canadian Aerobic Fitness Test in Female. Canadian Journal of Sport Science Vol 17, page 148-51.

Berger, R. A. 1982. Applied Exercise Physiology. Philadelphia: Saunders College.

Bompa, T. O. 1999. Programs For Peak Strength in 35 Sports. Periodization, Training for Sports. USA. Human Kinetics Publishing

Bompa, T. O., Gregory G. H. 2009. Periodization, Theory and Methodology of Training. USA : Human Kinetics Publishing Boreham, C.A.G, Kennedy, R.A, Murphy M.H, Walace, Q.F.M, Young I. 2006. The Physiology of Training. Philadelphia : Churchil Livingstone Elsevier

Breslow L, Enstrom J.E. 1980. Persistence of Health Habits and Their Relationship to Mortality. Journal of Prev Med. Vol 9 Jul Chap 4 page 469-483. Brouha L, Health C.W, Graybiel A. 1943. Step Test Simple Method of Measuring Physical Fitness for Hard Muscular Work in Adult Men. Journal Rev Canadian Biol, Vol 2:86

Brick, L. 2001. Bugar Dengan Senam Aerobik (Terjemahan). Jakarta: PT. Raja Grafindo Persada

Chandler, T.J, Brown L. 2008. Conditioning for Strength and Human Performance. Philadelphia; Lippincott Williams dan Wilkins.

Chin-Mou, Kuei-Fu. 2007. Estimation of VO2max : A Comparative Analysis of PostExercise Heart Rate and Physical Fitness Index from 3-Minutes Step Test. Journal of Exercise Sci Fit, Vol 5 No 2. [Cited 2013 Mar 29]. Available at : www.nhcue.edu.tw/j_exerc_sci_fit/vol5_20 07.

Cooper K.H. 2005. Notes on Physical Fitness. [Cited 2013 Mar 10]. Avaiable at: www.ed.wright.edu/resources/froms and things/classnotes/hpr.notes

.physical fitness $\% 20$ pdf.

Corbin C, Welk G, Cornin W.R, Welk K.A. 2008. Concepts of Fitness and Wellness 7th Edition. America : McGraw Hill International.

Dinata, M. 2003. Senam Aerobik dan Peningkatan Kesegaran Jasmani. Lampung : Penerbit Cerdas Jaya.

Fox, E. L. 1998. Sport Physiology. USA. CBS College Publishing.

Ganong, F. W. 2002. Buku Ajar Fisiologi Kedokteran (Terjemahan) Edisi 20. Jakarta : Penerbit Buku Kedokteran EGC

Giriwijoyo S, Muchtamaji, H. 2005. Ilmu Faal Olahraga. Fungsi Tubuh Manusia Pada Olahraga. Bandung; Universitas Pendidikan Indonesia, Fak Pendidikan Olahraga dan Kebugaran.

Giriwijoyo S, Sidik Z. 2010. Fisiologi Olahraga. Fungsi Tubuh Manusia pada Olahraga untuk Kebugaran dan untuk Prestasi. Bandung; Universitas Pendidikan Indonesia, Fak Pendidikan Olahraga dan Kebugaran.

Giriwijoyo. 2003. Wanita dan Olahraga. Jakarta. Fakultas Pendidikan Olahraga dan Kebugaran, Universitas Pendidikan Indonesia.

Golding, L.A. 2000. YMCA Fitness Testing and Assesment Manual. 4th Edition. USA. Human Kinetics Publishing.

Guyton, A.C, Hall J.E. 2006. Buku Ajar Fisiologi Kedokteran (terjemahan). Edisi 11. Jakarta : Penerbit Buku Kedokteran EGC.

Harsono. 2003. Prinsip-Prinsip Pelatihan Fisik. Jakarta : KONI Pusat.

Haskell, W, Franklin, B.A. 2009. ACSM's Guidelines for Exercise Testing Prescription. 8th edition. American College of Sport Medicine. Philadelphia : Lippincot Williams dan Wilkins

Hattiwale, H.M, Maniyar, S.A, Kusal, K.D, Dhundasi S. 2008. Role of BMI on Physical Fitness Index in Two Different Age Groups of Healthy Young Males From North 
Jurnal Perempuan dan Anak Indonesia

Interior Karnataka, India. Journal of Medical Science Al Ameen Vol 1 Chap 1 page 50-54. India : Dep of Physiology Al Ameen College Bijapur.

Irianto, J.P. 2004. Pedoman Praktis Berolahraga untuk Kebugaran dan Kebugaran. Yogyakarta, Penerbit Andi.

Juliantine T, Yudiana Y, Subarja H. 2007. Teori Latihan, Modul Mata Kuliah. Bandung : Universitas Pendidikan Indonesia, FPOK Jur. Penjaskes dan Rekreasi.

Kartinah, N.T, Komariyah, L, Giriwijoyo, S. 2006. Sport Medicine. Fakultas Pendidikan Olahraga dan Kebugaran Universitas Pendidikan Indonesia.

Kenney, L.W, Wilmore J.H, Costill D.L. 2012. Physiology of Sport and Exercise 5th Edition. USA; Human Kinetics.

Kushartanti, B.M. 2012. Manfaat Senam Bagi Kebugaran. Yogyakarta. Universitas Negeri Yogyakarta, Fakultas Ilmu Keolahragaan.

Kusmana, D. 2007. Olahraga Untuk Orang Sehat dan Penderita Penyakit Jantung. Edisi 2. Jakarta : Fakultas Kedokteran Universitas Indonesia.

Mackenzie, B. 2013. BrianMac Sports Coach. Diambil kembali dari BrianMac Sports Coach: http://www.brianmac.co.uk/havard.htm.

Available at http://journal.unnes.ac.id /sju/index.php/jssfCipta.

Maksum A, Mutohir T.C. 2004a. Dampak Olahraga Terhadap Peningkatan Kualitas Hidup Masyarakat. Jakarta : Ditjen Olahraga.

Maksum A, Sumaryanto. 2004b. Pola Partisipasi Masyarakat Dalam Berolahraga. Jakarta : Ditjen Olahraga

Manuaba, I.B. 1998. Bunga Rampai Ergonomi. Kumpulan Artikel. Denpasar : Program Studi Ergonomi Fisiologi Kerja, Program Pasca Sarjana Universitas Udayana.

McGinnis, P. 2005. Biomechanics of Sport and Exercise 2nd Edition. New York; Human Kinetics Print.
Mutohir, T. C, Maksum A. 2007. Sport Development Index. Konsep, Metodologi dan Aplikasi. Jakarta : PT Indeks. Nala, IGN. 1998. Prinsif Pelatihan Olahraga (Monograf). Denpasar: Program Studi Fisiologi Olahraga Program Pasca Sarjana Universitas Udayana.

Nala, IGN. 2011. Prinsip Pelatihan Fisik Olahraga. Denpasar: Program Studi Fisiologi Olahraga.Program Pasca Sarjana Universitas Udayana.

Nopembri, S. 2012. Faktor Yang Mempengaruhi Aktivitas Jasmani Wanita (Menstruasi dan Osteoporosis). Yogyakarta. Universitas Negeri Yogyakarta, Fakultas Ilmu Keolahragaan Jurusan Pendidikan Olahraga.

Nossek, J. 1982. General Theory of Training. Lagos: Pan Efrican Press Ltd.

Parks, J.B, Beverly Z. 1990. Sport and Fitness Management. United States of America : Human Kinetics Book, Champaign, Illinois.

Perry, S. 2008. Improving Cardiovascular Health and Fitness. [Cited : Mei 18th 2013]. Available at: www.freeengineering.com.

Poccock, S.J. 2008. Clinical Trials, A Practical Approach. London; John Willey dan Sons Publication.

Pollowck, M.L. dan Wilmore, J.H. 1990 Excercise in Health and Disease : Evaluation and Prescription for Prevention and Rehabilitation. 2nd. Ed. Saunders, Philadelphia.

Ratmawati, Y. 2013. Latihan Aerobik Intensitas Sedang dengan Diet Rendah Kolesterol Lebih Baik dalam Memperbaiki Kognitif daripada Intensitas Ringan pada Penderita Sindroma Metabolik (Tesis). Denpasar : Universitas Udayana. Santo, A.S, Golding, L.A. 2003. Prediction Maximum Oxygen Uptake from a Modified 3 minutes Step Test. Journal Res Q exercise Sport 74:1105.

Santosa. 2004. Statistik. Yogyakarta : Penerbit Andi. 


\section{Jurnal Perempuan dan Anak Indonesia}

Sharkley, B.J. 2003. Kebugaran dan Kebugaran (Terjemahan). Jakarta. PT. Raja Grafindo Persada.

Smotheman, R. 1996. Cross Validation of the Kash Three Minutes Step Test. Master Thesis. San Jose State University. [Cited 2012 Mar 22]. Available at : http://scholarworks.sjsu.edu/etd_thesis.

Sommer, C. 2008. The Science of Gymnastics Strength Training. Building the Gymnastic Body. USA; Seven Summits.

Sudarno, S.P, 1992. Pendidikan Kebugaran Jasmani. Jakarta: Depdikbud Dirjendikti Proyek Pembinaan Tenaga Kependidikan.

Sudarsono, N. C. 2008. Kebugaran. Fitness and Art. [Cited 2013 Mar 2]. Available at : staff.ui.ac.id/internal/140222109/material/k ebugaran.pdf

Sudarsono, S. 2011. Penyusunan Program Pelatihan Berbeban Untuk Meningkatkan Kekuatan. Jurnal Ilmiah SPIRIT, Vol. 11 No.3. FKIP UTP Surakarta. Available at : http://ejournal.utp.ac.id/index.php/jis/ article/view/35/33.

Suharno, H.P. 1993. Ilmu Kepelatihan Olahraga. Bandung : PT. Karya Ilmu.

Sukardiasih, N.L.G. 2005. Pelatihan Senam Ajeg Bali Lebih Meningkatkan Kebugaran Fisik dan Menurunkan Lemak Tubuh daripada Pelatihan Senam Ayo Bersatu pada Wanita Pegawai Puskesmas di Kecamatan Kediri Kabupaten Tabanan (Tesis). Denpasar; PPS Pascasarjana UNUD.

Sukron, M. A, Subiono H, Sutardji. 2012. Pengaruh Latihan Senam Aerobik Low Impact dan High Impact Terhadap Kesegaran Jasmani. Universitas Negeri Semarang, FIK Jurusan IKOR. Journal of Sport Sciences and Fitness. Cited 2013 Feb 22.

Sumosarjono, 2009. Pengetahuan Praktis dalam Olahraga. PT. Gramedia. Jakarta.

Suta, I.W.A. 2010. Pelatihan Senam Indonesia Jaya Lebih Meningkatkan Beugaran Fisik Daripada Pelatihan Jalan Aerobik
Mahasiswa Jurusan Kebidanan Poltekkes Depkes Denpasar (Tesis). Denpasar : Universitas Udayana.

Tilarso, B. 2008. Low Impact Aerobics. [Cited 2013 Mar 5]. Availabe at : www.mahening.blogspot.com/2008/03/low -impact-aerobic-berty- tilarso.html.

Tozeren, A. 2000. Human Body Dynamics : Classical Mechanics and Human Movement. Washington : Springer-Verlag New York, Inc.

Utomo G, Junaidi S, Rahayu S. 2012. Latihan Senam Aerobik Untuk menurunkan Berat Badan, Lemak dan Kolesterol. Journal Of Sport Science and Fitness, Vol 1 Jan 2012. Available at : http://journal.unnes. ac.id/sju/index.php/jssf.

Weatherwax-Fall, D. 2008. Komposisi Tubuh dan Efeknya pada Spektrum Performa Olahraga (Terjemahan). NSCA's Performance Training Journal - Colorado. Cited 2013 Mar 2. Available at : www.olympic. or.id /files/documents/journal/7.5.pdf.

Wirahadikusumah, E. 2000. Cara Aman dan Efektif Menurunkan Berat Badan. Jakarta : PT. Garuda Pustaka Utama.

Wirata, I.K.S. 2012. Pelatihan Senam Ayo Bersatu Meningkatkan Kebugaran Fisik Lebih Baik daripada Senam Indonesia Jaya Siswa Sekolah Dasar Negeri 3 Duda Selat Karangasem (Tesis). Denpasar : PPS Unud. 